\title{
Does Institution Affect the Inflow of FDI? A Panel Data Analysis of Developed and Developing Countries
}

\author{
Asiya Siddica $^{1} \&$ Mir Tanzim Nur Angkur ${ }^{2}$ \\ ${ }^{1}$ Senior Lecturer, Department of Economics, East West University, Bangladesh \\ Correspondence: Asiya Siddica, Senior Lecturer, Department of Economics, East West University, Bangladesh. \\ E-mail: asc@mail.ewubd.edu
}

Received: May 6, 2017

Accepted: June 3, 2017

Online Published: June 20, 2017

doi:10.5539/ijef.v9n7p214

URL: https://doi.org/10.5539/ijef.v9n7p214

\begin{abstract}
The objective of this paper is to study the institutional impact on the net FDI inflow along with the other possible determinants of Foreign Direct Investment (FDI) in 40 countries comprising of developing and developed countries over the period of 1990-2010 by using panel econometric model. The dependent variable of our study is log of net FDI inflows measured at current US million dollars of different countries in different points in time and independent variables are log of GDP measured at current US dollars, total trade as a share of GDP, gross fixed capital formation as a share of GDP, inflation as measured by consumer price index (annual \%) and log of composite index for infrastructure and a number of institutional variables such as investment profile, law and order and bureaucratic quality. According to the econometric results, the coefficients of log of GDP, trade to GDP ratio, gross fixed capital formation (\% GDP), and log of composite index for infrastructure and institutional variables are positive and significant but coefficient of inflation (\%, CPI) is negative and significant. Moreover, the institutional variables- investment profile and law and order have positive effect on FDI and bureaucratic quality has negative effect and also statistically significant.
\end{abstract}

Keywords: foreign direct investment, institutional variables, panel econometric model

\section{Introduction}

Foreign Direct Investment (FDI) plays an important role in accelerating the economic growth of a country. It enhances the productive capacity of the country through transfer in technology, introduction of new managerial practice and human capital development.FDI creates the opportunities to integrate the domestic economy with the Global market through foreign technology and institutional arrangements. According to Global Investment Trends Monitor published by UNCTAD (Note 1), the growth of FDI is projected to resume in 2017 and it transcend \$1.8 trillion in 2018 which indicating increasing growth globally. Both developed and developing countries are experiencing increasing surge of FDI which is almost doubled to $\$ 962$ billion and $\$ 765$ billion in 2015 respectively (Note 2).

Foreign Direct investment (FDI) has been regarded as an important source for enhancing the productive activity of the host countries which in turn affect the economic growth of a country. It works as an added advantage of a country through diffusion of knowledge, technology spillover and development of human capital. Many countries are providing various incentives like minimum wage, lower corporate tax, establishment of special economic zones, removal of tariff and moderate price level to attract more capital inflow. But having good economic condition, some of the countries are still fail to attract more capital flows compare to other. The country with stable economic condition accompanied with better institutional quality, good governance would be able to attract large share of FDI.

Foreign Direct Investment based on the idea that it takes place in lower cost location by shifting the production activity. According to the theory of international capital flows, the share of FDI varies due to the difference in abundance of resources and returns to capital. But in reality the story is different. The developed countries are able to attract large share of FDI where resource availability and rate of return are not that great. On the other hand the developing countries are not considered as the favorable place for FDI, despite of large market and abundant resources. So the main intention is to find out what factors mostly affect FDI.

Historically, the trend of FDI reveals that developed countries are considered as most favored place rather than 
developing countries. Table 1 shows that in earlier 1970 ,the share of FDI in developed countries consists of $71.6 \%$ to the world's total in contrast with developing countries with was only $28.4 \%$ (Source: UNCTAD).

Table 1. Share of FDI in the world (percentage in total world)

\begin{tabular}{lcc}
\hline & \multicolumn{2}{c}{ Percentage of Total World } \\
\cline { 2 - 3 } Year & Developing countries & Developed countries \\
\hline 1970 & $28.4 \%$ & $71.6 \%$ \\
1982 & $45.5 \%$ & $54.5 \%$ \\
1994 & $40.2 \%$ & $59.8 \%$ \\
2014 & $54.7 \%$ & $45.3 \%$ \\
2015 & $43.4 \%$ & $56.6 \%$ \\
\hline
\end{tabular}

Sources: (UNCTAD, World Investment Reports).

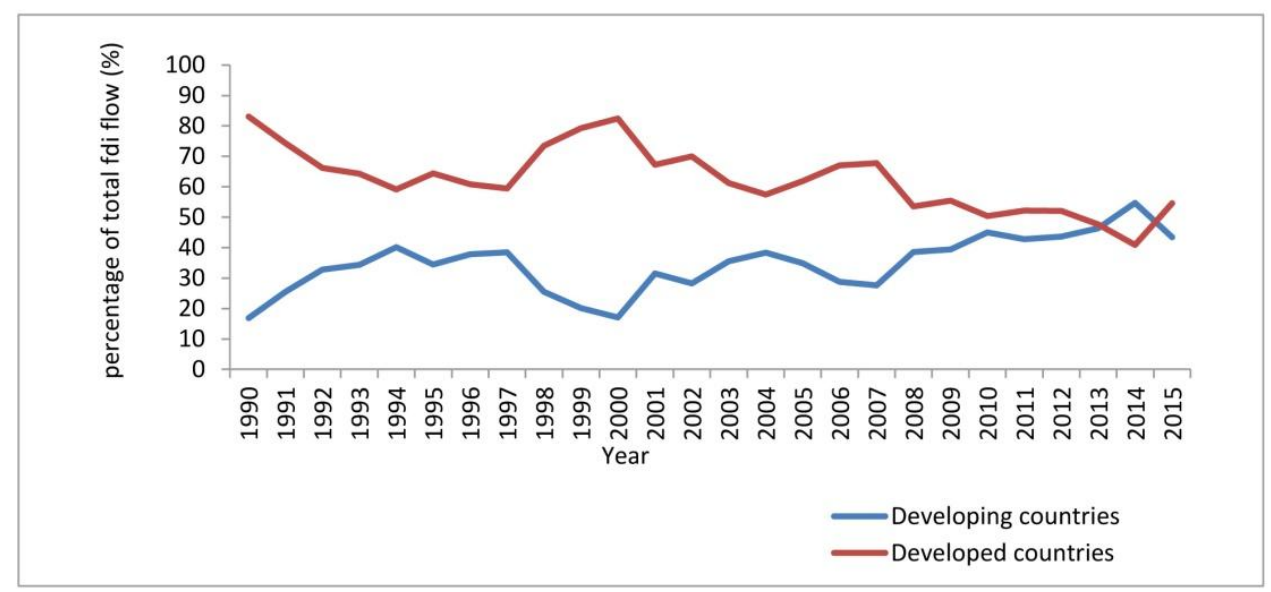

Figure 1. Trends of FDI inflow in developing and developed countries

Sources: (UNCTAD, World Investment Reports).

Moreover, it started increasing in developing countries since 1980 and onward and reaches its maximum in 2014 which is around 54.7\% but then take the lead the year after. The trends of FDI inflow in Figure 1 also matches with the results of large and dominant share of FDI in developed countries.

More recently, the literature has been deeply concentrated to find out the evidence on FDI and institutions link (Globerman \& Shapiro, 2002; Busse \& Hefeker, 2005; Benassy-Quere et al., 2005). Policy makers believe that the country with good institutional quality may able to attract more foreign capital but surprisingly the evidence is not satisfactory and no conclusion can be derived in general. The study by Lim (2001) and Blonigen (2005) attempted to estimate the effect of institution and FDI but the results is not satisfactory and there is further scope for future research. This allows us to investigate the effect of governance indicator to capture the institutional quality on the locational choice of foreign investor.

In this context, this study is intended to analysis the institutional aspect that could affect the net FDI inflows in the selective countries by examining long recent data. The analysis found significant empirical evidences that the determinants of FDI inflows to the selected countries are market size, trade openness, inflation, infrastructure and institutional variables.

The paper is organized as follows: Section II reviews previous studies about the determinants of FDI; Section III discusses data and methodology; Section IV presents empirical results; and Section V concludes the paper.

\section{Literature Review}

Extensive researched has been done regarding the determinants of Foreign Direct Investment (FDI) in developing countries. The most important factors that will motivate the MNE's towards shifting the production in the host countries are market size, infrastructure, geographical location, interest rate, inflation, trade openness, labor cost and tax incentives. (Demirhan \& Masca, 2013; Vijayakumar \& Sridharan, 2010; Bhavan \& Xu, 2011; Blonigen \& Piger, 2011; OnyeiWu \& Shrestha, 2004). 
Recently the institutional impact on the inflow of foreign direct investment has received higher level of attention to identify the locational advantage of MNEs' which is less researched. The country with good institutions tends to have positive effect on productivity with less uncertainty and higher expected rates of return. The quality of good institutions are required to attract more foreign direct investment into the country that can be ensured by stable law and order situation, transparent judicial system and property rights.

In the earlier study by Wheeler and Mody (1992) pointed out insignificant relationship of the first principal component of 13 risk factors (such as bureaucratic red tape, political instability, corruption and quality of the legal system) on the location of US foreign affiliates. Later on Wei $(1997,2000)$ found that corruption is the major and significant obstacle for inward FDI. But it loses its importance not to consider from the wider aspects of institutional variables and presence of colinearity between GDP per capita and corruption which has been challenged by Daude and Stein (2001).Political instability and violence, government effectiveness, regulatory burden, rule of law and graft are considered as significant determinant of FDI in contrast with insignificant indicator voice and accountability (Kaufman et al., 1999).

Globerman and Shapiro (1999) assert that both inward and outward FDI may have changed for same factors. He emphasized that good governance could have a positive impact on outward FDI and makes preferred condition for the multinational companies to invest abroad. Globerman and Shapiro (2002) further enhanced their research by estimating the impact of first principal component of the six governance indicators by Kaufman et al. (1999) on both inflow and outflow of FDI and found positive impact on both.

Brunetti and Weder (1999) have studied the impact of rule of law and high level of corruption on private investment in the 60 countries which is negative and highly significant. Various studies try to focus on the single governance variable such as corruption on FDI flows rather than multiple or composite scale. (Habib \& Zurawicki, 2002; Zhao, Kim, \& Du, 2003). International difference in private investment are sensitive to the risk factors faced by the multinational corporations. (Barro, 1996; Sala-i-Martin, 1997).

Gastanaga et al. (1998) investigate the policy and institutional variables (contract enforcement, nationalization risk and bureaucratic delay) on FDI and found a significant association among them. The study by Asiedu (2005) tries to establish the impact of institutional variables with the non-policy variables such as market size and natural resources. They conclude that the country with scarce natural resources can attract more FDI by providing good governance.

Mauro (1995) estimate that corruption has negative and significant impact on the ratio of total and private investment to GDP which creates serious impediment to economic growth. The above mentioned studies exerts that institution does matter for FDI. However, some studies by Asiedu (2002), Noorbakhsh et al. (2001), Harms and Ursprung (2002) and June and Singh (1996) fail to relate the institutional impact and FDI flows. This failure could be responsible for taking small sample and considering a single index such as rule of law for capturing a broad complex factor like institutions. A comprehensive measurement of institutional quality can be a good reflection to capture the impact of institution on FDI.

We try to contribute to the existing literature by considering various institutional variables such as investment profile, bureaucratic quality and law and order. This has been taken from the International Country Risk Guide (ICRG) dataset complied by PRS Group.

In summary, the findings of the previous literature review showed that government institutions can play a vital role in determining the FDI inflow. The country with good and strong institutions may be able to attract large share of FDI than other. The contribution of our paper is to show the impact of such institutions on FDI inflows in a number of countries.

\section{Data and Methodology}

In this paper we will try to determine the effects of institutional variables on FDI inflows of some selected developed and developing countries (Table 2). We have used purposive sampling in this analysis, where countries are selected on the basis of availability of the relevant data. The data set was prepared from data published by the World Bank, WDI (Note 3) and International Country Risk Guide (ICRG) dataset for institutional variables. For the analysis we have used a panel data set that covers a sample of 40 countries and spans the period from 1990 through to 2010.

\subsection{Specified Model and the Variables of Interest}

According to most of the previous studies, the above discussed explanatory variables were found to have affected the net FDI inflows of a country. For the current study, we propose the following panel regression equation model: 


$$
\begin{aligned}
& \log _{-} f d i_{i t}=\beta_{o}+\beta_{I} l o g \_g d p_{i t}+\beta_{2} \text { Gross_fixed_capital_form }{ }_{i t}+\beta_{3} T r a d e \_t o \_G D P_{i t}+\beta_{4} \text { Inflation }(c p i)_{i t}+ \\
& \beta_{5} \text { log_comp_infra }+u_{i t} \\
& \log _{\_} f d i_{i t}=\beta_{o}+\beta_{1} l o g \_g d p_{i t}+\beta_{2} \text { Gross_fixed_capital_form } i t+\beta_{3} \text { Trade_to_GDP } i t+\beta_{4} \text { Inflation }(c p i)_{i t}+ \\
& \beta_{5} \log _{-} \text {comp_infra }+\beta_{6} \text { Insti_var }+u_{i t}
\end{aligned}
$$

Where,

$\log _{-} f d i_{i t}$ is $\log$ of net Foreign Direct Investment in current US\$ millions for country $i$ at time t.

$\log _{\_} g d p_{i t}$ is $\log$ of annual Gross Domestic Product in current US\$ for country $\mathrm{i}$ at time $\mathrm{t}$ and is the proxy of market size.

Gross_fixed_capital_form $m_{i t}$ is defined as gross fixed capital formation (formerly gross domestic fixed investment) includes land improvements (fences, ditches, drains, and so on); plant, machinery, and equipment purchases; and the construction of roads, railways, and the like, including schools, offices, hospitals, private residential dwellings, and commercial and industrial buildings.

Trade_to _ $G D P_{i t}$ is the openness of a country $\mathrm{i}$ at time $\mathrm{t}$ and is computed as ratio of import and export of goods and services divided by GDP.

Inflation is inflation as measured by the consumer price index reflects the annual percentage change in the cost to the average consumer of acquiring a basket of goods and services that may be fixed or changed at specified intervals, such as yearly. It is taken as a proxy for economic stability for a country;

log_comp_infra is used as a proxy for infrastructure and it is computed by taking simple average of two infrastructure variables-fixed telephone subscriptions (per 100 people) and internet users (per 100 people) and then measured in logs represents the performance indicator of various countries at different time.

insti_var is the set of institutional variables taken for country $i$ at time $t$ which are the indicator variables of our model.

The expected sign of $\log \_g d p_{\text {is }}$ positive implying that the larger the market size for any country the more opportunities it generates for potential foreign investors. For the variable Gross_fixed_capital_form, it is expected to have a positive sign indicating that those countries which have already a good capital base tend to attract more FDI. The expected sign of Trade_to _GDP is positive which implies that foreign investors may prefer to invest in those countries which tend to more open and have a liberal trade regime.

On the other hand, it is expected that inflation have a negative sign indicating that countries with a low rate of inflation will encourage potential foreign investors to invest since it shows the economy is stable and there is more chance of achieving higher rate of return on investment. It is also been found that potential investors prefer to invest in those countries which have a better infrastructure. So for this reason we may expect to a positive sign for log_comp_infra is used as a proxy for infrastructure.

insti_var represents institutional variables and we have taken investment profile, bureaucratic quality and law and order. Investment profile represents an assessment of factors affecting the risk to investment. The risk rating assigned is the sum of three subcomponents namely contract viability/expropriation, profits repatriation and payment delays, each with a maximum score of four points and a minimum score of 0 points. A score of 4 points equates to Very Low Risk and a score of 0 points to Very High Risk. The aggregate sum ranges from 0(Very High Risk) to 12 (Very Low Risk). Therefore a higher value indicates lower risk and encourages more FDI inflows.

Bureaucratic quality shows the institutional strength and quality of the bureaucracy is another shock absorber that tends to minimize revisions of policy when governments change. Therefore, high points are given to countries where the bureaucracy has the strength and expertise to govern without drastic changes in policy or interruptions in government services. It may also represent the expertise to negotiate better with foreign investors while keeping the country's interest intact. Therefore may have a detrimental effect on FDI inflows into those countries. The value ranges from 0 to 4 .

Law and order is an assessment of the strength and impartiality of the legal system. Thus, a country can enjoy a high rating exhibits low crime rate but a low rating indicates it suffers from a very high crime rate of if the law is routinely ignored without effective sanction (for example, widespread illegal strikes). So a higher value will attract investors to invest while a lower often discourages FDI inflows into those countries. The value of these ranges from 0 to 6 . 


\section{Empirical Results and Interpretation}

Using panel data first of all we have estimated the proposed basic model by both Random Effects (RE) and Fixed Effects (FE) estimation methods. The Table 3 presented the results of both estimations of FE and RE models along with the result of Hausman test which is carried out to determine which model either FE or RE fits better. We can conclude that since $0.0926>0.05$ (i.e. not significant) we should use random effects model. And also we used Hausman test for the basic model with institutional variables (Model-2, Model-3 \& Model-4) to determine which model either FE or RE fits better.

Table 2. Estimated regression results

\begin{tabular}{|c|c|c|c|c|}
\hline $\begin{array}{l}\text { Dependent Variable-Log of Net FDI Inflows } \\
\text { Independent Variables }\end{array}$ & $\begin{array}{c}\text { Random Effect } \\
\text { Model-1 }\end{array}$ & $\begin{array}{c}\text { Random Effect } \\
\text { Model-2 }\end{array}$ & $\begin{array}{l}\text { Fixed Effect } \\
\text { Model-3 }\end{array}$ & $\begin{array}{c}\text { Fixed Effect } \\
\text { Model-4 }\end{array}$ \\
\hline Log of GDP in current USD & $\begin{array}{c}0.977 * * * \\
(0.074)\end{array}$ & $\begin{array}{l}1.011 * * * \\
(0.082)\end{array}$ & $\begin{array}{c}0.961 * * * \\
(0.119)\end{array}$ & $\begin{array}{c}0.897 * * * \\
(0.116)\end{array}$ \\
\hline Trade to GDP ratio & $\begin{array}{c}0.010 * * * \\
(0.002)\end{array}$ & $\begin{array}{c}0.011 * * * \\
(0.002)\end{array}$ & $\begin{array}{c}0.016 * * * \\
(0.003)\end{array}$ & $\begin{array}{c}0.016^{* * * *} \\
(0.003)\end{array}$ \\
\hline $\begin{array}{l}\text { Gross Fixed Capital Formation } \\
(\% \text { GDP })\end{array}$ & $\begin{array}{c}0.044 * * * \\
(0.008)\end{array}$ & $\begin{array}{c}0.036 * * * \\
(0.009)\end{array}$ & $\begin{array}{c}0.052 * * * \\
(0.001)\end{array}$ & $\begin{array}{l}0.060 * * * \\
(0.001)\end{array}$ \\
\hline $\operatorname{Inflation}(\%, \mathrm{CPI})$ & $\begin{array}{l}-0.001 * * * \\
(0.0002)\end{array}$ & $\begin{array}{l}-0.001 * * * \\
(0.0002)\end{array}$ & $\begin{array}{l}-0.001 * * * \\
(0.0002)\end{array}$ & $\begin{array}{l}-0.001 * * \\
(0.0002)\end{array}$ \\
\hline Log of Composite Index for Infrastructure & $\begin{array}{l}0.010^{* *} \\
(0.003)\end{array}$ & $\begin{array}{c}0.001 \\
(0.005)\end{array}$ & $\begin{array}{c}0.013 * * \\
(0.004)\end{array}$ & $\begin{array}{c}0.013 * * \\
(0.004)\end{array}$ \\
\hline Investment Profile & - & $\begin{array}{c}0.102^{* * * *} \\
(0.025)\end{array}$ & & \\
\hline Law and Order & - & 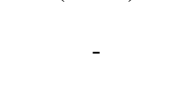 & $\begin{array}{c}0.0816^{* * * * *} \\
(0.055)\end{array}$ & \\
\hline Bureaucratic Quality & - & - & - & $\begin{array}{c}-0.591 * * * \\
(0.107)\end{array}$ \\
\hline Constant & $\begin{array}{c}-19.602 * * * \\
(1.88)\end{array}$ & $\begin{array}{c}-20.81 * * * \\
(2.11)\end{array}$ & $\begin{array}{c}-20.14 * * * \\
(2.95)\end{array}$ & $\begin{array}{c}-16.37 * * * \\
(2.98)\end{array}$ \\
\hline Observations & 925 & 740 & 740 & 740 \\
\hline R-Squared & 0.641 & 0.601 & 0.542 & 0.475 \\
\hline
\end{tabular}

For those institutional variables we have run three different regression equations shown as in equation-2 incorporating each one with the basic model as shown in equation-1. The results of those four models are given in Table 2.

Table 3. Summary of regression results and hausman test result

\begin{tabular}{lcc}
\hline Dependent Variable: log of net FDI inflow & & (Random Effects) \\
\hline Independent variables & Coefficient \\
& Coefficient & (Standard Error) \\
\hline log of Annual GDP & (Standard Error) & $0.977 * * *$ \\
Gross fixed capital formation & $0.876^{* * *}$ & $(0.074)$ \\
(\% of GDP) & $(0.097)$ & $0.044^{* * *}$ \\
Trade to GDP ratio & $0.055^{* * *}$ & $(0.008)$ \\
& $(0.009)$ & $0.010^{* * *}$ \\
Inflation(CPI) & $0.013 * * *$ & $(0.002)$ \\
& $(0.003)$ & $-0.001 * * *$ \\
Log of Composite Index for Infrastructure & $-0.001 * * *$ & $(0.007)$ \\
Constant & $(0.0002)$ & $0.010^{* * *}$ \\
\hline
\end{tabular}




\begin{tabular}{|c|c|c|c|}
\hline Number of observations & \multicolumn{2}{|r|}{925} & 925 \\
\hline $\mathrm{F}$ & \multicolumn{2}{|r|}{118.48} & --------- \\
\hline chi2 & \multicolumn{2}{|r|}{------- } & 710.25 \\
\hline $\mathrm{R}^{2}$ & \multicolumn{2}{|r|}{0.609} & 0.641 \\
\hline \multicolumn{4}{|c|}{ Hausman Test Result } \\
\hline \multicolumn{4}{|c|}{$\begin{array}{l}\text { Test: Ho: difference in coefficients not systematic } \\
\text { chi2 }(4)=(b-B)^{\prime}\left[\left(V_{-} b-V_{-} B\right)^{\wedge}(-1)\right](b-B)\end{array}$} \\
\hline \multicolumn{4}{|c|}{$=9.44$} \\
\hline \multicolumn{4}{|c|}{ Prob $>$ chi $2=0.0926$} \\
\hline
\end{tabular}

Note. $* * * \mathrm{p}<0.01,{ }^{* *} \mathrm{p}<0.05, * \mathrm{p}<0.1$.

From Table 2, it can be deduced that the empirical results have also conformed to the theoretical predictions of the model. In particular the coefficients of Log of GDP, Trade to GDP ratio, Gross fixed capital formation (\% GDP) and Log of Composite Index for Infrastructure are positive and significant and coefficient of Inflation (\%, CPI) is negative and significant in Model-1 which is the basic model.

Model-2 shows the effect of one of the institutional variable i.e. Investment profile. The coefficient of investment profile is positive and significant at $10 \%$ level of significance which suggests that on average countries with high values indicating low risk are able to attract more FDI than those countries with low values indicating high risk of investment. The foreign investors no doubt are likely to invest in those countries where risk of investment is low.

Model-3 shows the effect of another institutional variable i.e. law and order. The coefficient of law and order is positive and significant at $15 \%$ level of significance which suggests that on average countries with high values indicating better law and order situation thereby enticing the foreign investors. On the other hand, the potential investors are less likely to invest in those countries where law and order situation is poor and not conducive for domestic investment let alone FDI.

Model-4 shows the effect of third institutional variable we have taken in our study i.e. bureaucratic quality. The coefficient of bureaucratic quality is negative and significant at $10 \%$ level of significance which suggests that on average countries with high values indicating better institutional strength and quality of bureaucrats are found to have lower level of FDI. It could be the fact that countries having well informed bureaucrats are able to negotiate with foreign investors and may not easily cater to the demands of the foreign investors which might go against the interest of the FDI recipient countries.

\section{Conclusion}

Many researchers found common factors that affect the FDI inflow in a country but institutional impact is less researched. So this paper aims to analyze the institutional impact on the inflow of net FDI for the period of 1990 to 2010 for the selected countries. We have found that the institutional variables- investment profile and law and order have positive effect on FDI and bureaucratic quality has negative effect and also statistically significant .The potential foreign investors are less likely to invest in a country with the poor institutional framework. So we may conclude our paper by emphasizing the importance of institutional reform to attract large share of FDI. The overall significance of the model would be able to explain the country can achieve higher growth prospect not only relying on private investment but also open the possibility of foreign investment and can give some important policy implications.

\section{References}

A. K, J. G. (January 2013). Determinat of FDI in South Asia. International Research Journal of Social Sciences, 2(1), 1-6.

Agnes BENASSY-QUERE, M. C. (2005). Instituional Determinant of Foreign Direct Investment. CEPII, Working Paper No 2005-05.

Bhavan, T., Changsheng, X., \& Chunping, Z. (2010). Determinants and Growth effect of FDI in South asian Economies: Evidence from a panel Data Analysis. International Business Research, 4(1).

Cheryl, L., Jin, Y., \& Jing, Z. (2015). Institutional Impact of Foreign Direct Investment in China. World Development, 66, 31-48. https://doi.org/10.1016/j.worlddev.2014.08.001

Christian, D., \& Ernesto, S. (2004, February). The Quality of Institutions and Foreign Direct Investment. Economics \& Politics, 19(3), 317-344. 
David, A., \& Wernick, J. H. (2014). The Impact of Goverining Institutions on Foreign Direct Investment Flows: Evidence from African Nations. International Journal of Business Administration, 5(2).

Demir, F. (2016). Effects of FDI Flows on Instituitional Development in th e South: Does IT Matter Where the Investors are from? Journal World Dvelopment, 341-359.

Erdal, D., \& Mahmut, M. (2008). Determinants of Foreign Direct Investment Flows to Developing countries: A Cross -Sectional Analysis. Prague Economic Papers, (4), 356-369.

Fathi, A. Ali., Norbet, F., \& Ronald, M. (11 July, 2008). Do Institutions Matter for Foreign Direct Investment? Open Economies Review, 21(2), 201-219.

Guesmi, F. T. (November/December 2013). Determinants of Foreign Direct Investment in the South Asian Association for Regional Cooperation. The Journal of Applied Business Research, 29(6).

Kalirajan, K. A. (2010/13). Determinant of foreign Direct Investment in Developing Countries: A Comparative Analysis. ASARC Working Paper.

Levieuge, C. J. (2017). Growth effect of FDI in developing economies: The role of institutional quality. The World Economy, 40(4), 715-742. https://doi.org/10.1111/twec.12402

Lipsey, E. R. (July 2000). Interpreting Developed Countries Foreign Direct Investment. National Bereau of Economic Research, Social Science Electronic Publishing.

Moreira, S. B. (2009). The Determinant of Foriegn Direct Investment. UNISUL, 2(1), 83.

Narayanamurthy, V. P. S. (2010). Determiant of FDI in BRICS Countries: A Panel Analysis. International Journal of Business Science and Applied Management, 5(3).

Ngugi, R. W. (December, 2005). Institutional Factors and Foreign Direct Investment Flows: Implications for Keyna.

Raihan, S. (December 1, 2016). What factors matter in attracting FDI? Dhaka: SANEM, Thinking Aloud.

S, K. W. (November 2011). Foreign Direct Investment into Developing Asian Countries: The Role of Market Seeking, Resource seeking and Efficiency Seeking Factors. International Journal of Business and Management, 6(11).

Talamo, G. M. (n. d.). Institution, FDI and Gravity Model.

Varsakelis, M. P. (2004). Institutions, internationalization and FDI: The case of economies in transition. Transnational Corporations, 13(2), 77-94.

Wu, H. A. (Jan, 1994). Foreign Direct Investment in Developing countries. The Journal of Developing Areas, 167-190.

\section{Appendix}

Table 4. List of sample developing and developed countries

\begin{tabular}{cccc}
\hline S.L & List of Countries & S.L & List of Countries \\
\hline 1 & Korea, Republic of & 21 & Japan \\
2 & Argentina & 22 & Malaysia \\
3 & Australia & 23 & Mexico \\
4 & Austria & 24 & Morocco \\
5 & Bangladesh & 25 & Nepal \\
6 & Belgium & 26 & Netherlands \\
7 & Brazil & 27 & Norwaland \\
8 & Canada & 28 & Pakistan \\
9 & China & 29 & Singapore \\
10 & Colombia & 30 & South Africa \\
11 & Denmark & 31 & Spain \\
12 & France & 32 & Sri Lanka \\
13 & Germany & 33 & Sweden \\
14 & Greece & 34 & Switzerland \\
15 & Hong Kong & 35 & Syria \\
\hline
\end{tabular}




\begin{tabular}{lccc}
\hline 17 & Indonesia & 37 & Thailand \\
18 & Iran & 38 & Turkey \\
19 & Ireland & 39 & United Kingdom \\
20 & Italy & 40 & United states \\
21 & Japan & & \\
22 & Malaysia & \\
23 & Mexico & \\
24 & Morocco & \\
25 & Nepal & \\
26 & Netherlands & \\
28 & New Zealand & \\
29 & Norway & & \\
\hline
\end{tabular}

\section{Notes}

Note 1. United Nation Conference on Trade and Development.

Note 2. Global Investment Trends Monitor, UNCTAD.

Note 3. World Development Indicators.

\section{Copyrights}

Copyright for this article is retained by the author(s), with first publication rights granted to the journal.

This is an open-access article distributed under the terms and conditions of the Creative Commons Attribution license (http://creativecommons.org/licenses/by/4.0/). 